\title{
Assessment of Consumption Rate of Solid Biomass Fuels and the Consequent Environmental Impact in Maiduguri Metropolis
}

\author{
Hussaini Mohammed ${ }^{*}$, Hamza A. Dayyabu², Usman Muhammed² \\ ${ }^{1}$ Civil \& Water Resources Engineering Department, Faculty of Engineering, University of Maiduguri, \\ Maiduguri, Nigeria \\ ${ }^{2}$ Department of Civil \& Water Resources Engineering, Faculty of Engineering, University of Maiduguri, \\ Maiduguri, Nigeria \\ Email: *m.hussaini@unimaid.edu.ng
}

How to cite this paper: Mohammed, H., Dayyabu, H.A. and Muhammed, U. (2018) Assessment of Consumption Rate of Solid Biomass Fuels and the Consequent Environmental Impact in Maiduguri Metropolis. Open Journal of Air Pollution, 7, 34-47. https://doi.org/10.4236/ojap.2018.71003

Received: December 7, 2017

Accepted: March 6, 2018

Published: March 9, 2018

Copyright (c) 2018 by authors and Scientific Research Publishing Inc. This work is licensed under the Creative Commons Attribution International License (CC BY 4.0).

http://creativecommons.org/licenses/by/4.0/

\section{Open Access}

\begin{abstract}
A proper assessment of the rate of unsustainable consumption of biomass fuel is important to determine the extent of the consequent environmental effects. In this paper, an evaluation was made of the rate of fuelwood (firewood and charcoal) consumption in Maiduguri metropolis, the capital of Borno state in Nigeria. Firewood and charcoal are the main solid biomass fuels consumed in Maiduguri city, in addition to rarely used animal dung, thatch, leaves, etc. These fuels are usually used in households, markets and industries for cooking, roasting and bakery activities. To quantify the rate of consumption of these fuels in Maiduguri (and their eventual negative effects), data were collected on the rate of supply of the biomass along highways leading to the city. The result shows a total consumption rate of $366 \mathrm{t} /$ day of solid biomass fuel, with firewood accounting for $288 \mathrm{t} /$ day and charcoal makes up the remaining $78 \mathrm{t}$ /day. This fuelwood consumption rate is around $0.15 \%$ of the national figure. The resulting emissions of $\mathrm{CO}_{2}, \mathrm{CH}_{4}, \mathrm{~N}_{2} \mathrm{O}, \mathrm{SO}_{2}, \mathrm{NOx}, \mathrm{NMVOC}, \mathrm{CO}$, $\mathrm{NH}_{3}, \mathrm{PM} 10$ and PM2.5 in kg/day are 433,488, 2160, 46, 83, 394, 2796, 34,699, 19.01, 5031 and 4884 respectively. Emissions of greenhouse gases stood at 497 t COe/day or 181,314 t $\mathrm{CO}_{2}$ /year. A strategic shift to cleaner stoves and low carbon fuels is feasible and will enhance sustainable energy use.
\end{abstract}

\section{Keywords}

Charcoal, Deforestation, Emissions, Energy, Firewood

\section{Introduction}

Solid biomass fuel is the most widely used primary energy source in the devel- 
oping world because it is cheaper and easier to extract compared to liquid and gaseous fuels [1] [2] [3] [4] [5]. Biomass fuels are used in various areas like cooking, heating, electricity generation, etc. Examples of biomass include wood, charcoal, peat, animal dung, etc. This study focuses on assessing the rate of solid biomass fuel consumption in Maiduguri metropolis, the capital of Borno state in Nigeria. Nigeria is a developing country located in sub-Saharan Africa. Over 70\% of the population in developing countries depends on biomass as their primary fuel for cooking [6] [7]. However, the proportion of the population relying on biomass is highest in sub-Saharan Africa; in most cases with majority of the population relying on firewood and charcoal, accounting for over $90 \%$ of household energy consumption [3] [8]. In OECD countries, biomass demand comes mostly from the power generation and industry sectors, while in developing countries these sectors represent only $12 \%$ [3].

There are variations in the level of consumption and the types of fuels used. The main use of energy in households in developing countries is for cooking, followed by heating and lighting. Due to the nature of the geography and climate, household space and water heating needs are small in Nigeria. In Nigeria, especially in rural areas, majority of the people rely on firewood, charcoal, agricultural waste and animal dung, to meet their energy needs for cooking [9]. Household use of biomass in Nigeria accounts for almost $50 \%$ of cooking fuel [10].

Issues relating to the use of biomassas fuels have been a source of concern because of their adverse consequences for health and environment. The process of burning such fuels is associated with harmful emissions of particulate matter (smoke) and gaseous emissions as a result of incomplete combustion of the fuels [11]. Also, the process of collection and processing of these fuels is time consuming and requires tremendous energy. Continuous and unsustainable use of fuelwood leads to permanent removal of trees giving rise to deforestation. This phenomenon has negative environmental impacts including reduced biodiversity (loss of habitat leading to loss of animal and plant species), increased greenhouse gases due to lack of $\mathrm{CO}_{2}$ absorption, soil erosion and flooding [12] [13]. And considering population growth and the consequent demand for energy in Nigeria, this negative effect will continue to intensify geometrically.

Therefore, the paper will critically look into the rate (and areas) of biomass consumption, the resulting harmful emissions and their effects on the environment and ways to provide solutions to those effects. The paper is structured as follows. Section 1 is the introduction which gives an overview of the paper work, including aims and objectives, scope and the study area. Section 2 presents the methodology and primary data obtained from the field. Section 3 deals with the explanation of the secondary results sourced from the field data and what this means to the society. The consequent environmental effects of biomass consumption are elucidated here. Section 4 draws conclusions from the work and put forward some recommendations for further steps towards a sustainable environment. 


\subsection{Aim and Objectives of the Study}

The aim of this paper is to determine the rate of consumption of solid biomass fuels in Maiduguri metropolis and suggest ways of minimizing the resulting health and environmental consequence.

The objectives are:

- To determine the rate of biomass fuel (firewood and charcoal) supply into Maiduguri city;

- To evaluate the rates of harmful emissions due to biomass combustion using wood densities and emissions conversion factors from the literature.

Since there is no special place where firewood and charcoal are continuously accumulated in the city, and also the variations of the fuel quantities with wholesalers, retailers and final consumers are not biased in any direction but rather at any given time, swinging about a particular center point as an average, we can conveniently assume that equal amount of the daily supply into the city is consumed on a daily basis in the city. The daily supply is used to replace the daily demand for the fuels within the city, and hence is equal to the daily consumption by the city. Therefore, data on the daily supplies are used to estimate the rate of consumption of biomass within Maiduguri. Consumption of other biomass fuels (such as animal dungs, thatch, leaves, etc.) in Maiduguriis considered negligible.

\subsection{The Study Area}

Maiduguri is the oldest city in the north-eastern part of Nigeria. It is roughly located betweenlatitudes $11^{\circ} 46^{\prime}$ to $11^{\circ} 53^{\prime} \mathrm{N}$ and longitudes $13^{\circ} 2^{\prime}$ to $13^{\circ} 13^{\prime} \mathrm{E}$ [14]. The region was home to the Kanem-Bornu Empire for centuries. Currently, the city has a population of about $1,146,397$ people (with a growth rate of $+1.51 \% / y r$ ), which is about $0.6 \%$ of Nigeria's total population [15]. With an area of $330 \mathrm{~km}^{2}$, the population density is around 3470 inhabitants per $\mathrm{km}^{2}$ [14]. Its population is largely Muslims, consisting of various ethnic groups including Kanuri, Shuwa Arab, Pabr-Bura, Margi, Fulani, etc. According to Köppen-Geiger climate classification system, the climate nature of Maiduguri is hot semi-arid. It has average high temperatures ranging between $31.9^{\circ} \mathrm{C}\left(89.4^{\circ} \mathrm{F}\right)$ in January and $40.1^{\circ} \mathrm{C}\left(104.2^{\circ} \mathrm{F}\right)$ in April whereas the daily mean temperatures range between $21.8^{\circ} \mathrm{C}\left(71.2^{\circ} \mathrm{F}\right)$ in January to $32.6^{\circ} \mathrm{C}\left(90.7^{\circ} \mathrm{F}\right)$ in April [16] [17] [18]. The highest temperature record was $47^{\circ} \mathrm{C}\left(117^{\circ} \mathrm{F}\right)$ in May 28,1983 and the lowest temperature record was $5^{\circ} \mathrm{C}\left(41^{\circ} \mathrm{F}\right)$ on December 26, 1979 [16] [19]. Maiduguri city is bordering with three countries of Cameron, Chad and Niger and that makes it a strategic commercial center for trans-national exchange of goods across the country's borders. These figures indicate that energy demand is likely to be significant in the city and that the resulting environmental consequence would require innovative strategies to overcome.

\section{Methodology and Data}

The daily consumption of firewood (FWD) and charcoal (CHL) in Maiduguri 
metropolis was estimated by taking data at entry points along highways along which the fuels are usually conveyed into the city. This is because fuelwood is prepared and processed outside the city before transporting them in along these roads. Hence, an estimate of the number of charcoal bags (together with the average mass of charcoal bag) and the volume of firewood (with the firewood density known) carried by each vehicle into the city along those roads (Bama, Dikwa, Damasak, Kashim Ibrahim and Gombe roads) will result to a fair assessment of the daily masses of biomass energy sources consumed within the city. The volume of firewood carried by the vehicles is directly measured and the firewood density (sourced from literature based on the wood type) is used to convert the volume into mass and evaluate the total daily mass supply into the city. For charcoal, the numbers of bags are recorded from the suppliers and the established average mass of a charcoal bag is used to calculate the total daily mass supply. Figure 1 below shows google map of Maiduguri Metropolis, the main highways leading to the city and the data collection points along the highways (shown in black circles).

The average mass of a bag of charcoal is determined by visiting three different charcoal business centers/dealers within the city. From each dealer, three bags are taken at random and weighed separately using a hanging scale to obtain their masses after which the average mass of the three bags is calculated. Similarly for the next two dealers, the averages of three bags picked at random are calculated to obtain a total of three averages of three bags each. Then, the average of the three averages (the overall average, AVG) is calculated further to achieve a more accurate representative mass of a charcoal bag.

Therefore;

$$
\begin{aligned}
\text { Overall average AVG } & =\frac{\text { Avg Dealer1 }+ \text { Avg Dealer2 }+ \text { Avg Dealer3 }}{3} \\
& =\frac{\frac{33+35+34}{3}+\frac{33+32+34}{3}+\frac{34+32+35}{3}}{3}=34 \mathrm{~kg}
\end{aligned}
$$

Information on the ratio of the type of wood used as firewood and charcoal was also collected. The trees used are mainly neem and various species of acacia. Along each road, two full days are used for data collection and their average is used as the daily intake through that road. Several tens of firewood and charcoal carrying vehicles enter the city from various entry points. Table 1 below presents the total daily intake of firewood and charcoal fuels on the selected data collection days.

\section{Result and Discussion}

Supplies of biomass are abundant in many communities in Nigeria as they are in Maiduguri metropolis. This is because they are the only affordable energy source for majority of households in the developing countries. The commercial production and distribution of firewood and charcoal generates significant employment and income in rural as well as urban areas [23] [24] [25]. In the absence of policy 


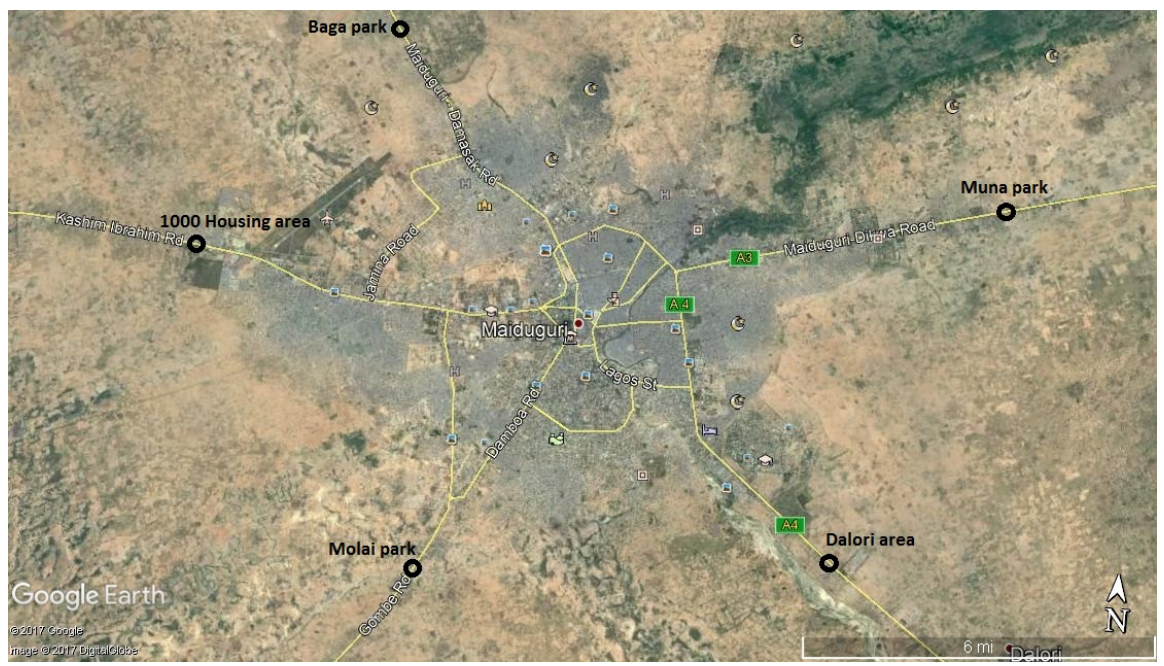

Figure 1. Map of Maiduguri City showing data collection points [20].

Table 1. Rate of fuelwood supply/consumption in Maiduguri (Fieldwork, 2017).

\begin{tabular}{|c|c|c|c|c|c|c|c|c|c|c|c|}
\hline \multirow{3}{*}{$\begin{array}{l}\text { Data collection } \\
\text { point }\end{array}$} & \multirow{3}{*}{$\begin{array}{c}\text { Data } \\
\text { collection } \\
\text { day }\end{array}$} & \multicolumn{3}{|c|}{ Firewood } & \multicolumn{3}{|c|}{ Charcoal } & \multirow{2}{*}{\multicolumn{2}{|c|}{ Average daily supply }} & \multirow{2}{*}{\multicolumn{2}{|c|}{$\begin{array}{c}\text { Frequency of wood } \\
\text { type }\end{array}$}} \\
\hline & & \multirow{2}{*}{$\begin{array}{l}\text { Vol. of } \\
\text { FWD } \\
\left(\mathrm{m}^{3}\right)\end{array}$} & \multirow{2}{*}{$\begin{array}{l}\text { Mass of } \\
\text { FWD }(\mathrm{kg})\end{array}$} & \multirow{2}{*}{$\begin{array}{c}\text { Type of } \\
\text { wood } \\
(\mathrm{A} / \mathrm{N})\end{array}$} & \multirow{2}{*}{$\begin{array}{l}\text { No. of } \\
\text { CHL } \\
\text { bags }\end{array}$} & \multirow{2}{*}{$\begin{array}{l}\text { Mass of } \\
\text { CHL (kg) }\end{array}$} & \multirow{2}{*}{$\begin{array}{c}\text { Type of } \\
\text { wood } \\
(\mathrm{A} / \mathrm{N})\end{array}$} & & & & \\
\hline & & & & & & & & $\begin{array}{l}\text { FWD } \\
\left(\mathrm{m}^{3} / \mathrm{d}\right)\end{array}$ & $\begin{array}{c}\text { CHL } \\
\text { (bags/d) }\end{array}$ & $\begin{array}{l}\text { FWD } \\
(A / N)\end{array}$ & $\mathrm{CHL}(\mathrm{A} / \mathrm{N})$ \\
\hline \multirow{2}{*}{ Bama Rd } & Day 1 & 71 & 48,177 & $6 / 19$ & 341 & 11,594 & $9 / 10$ & \multirow{2}{*}{80.5} & \multirow{2}{*}{502} & \multirow{2}{*}{$6 / 23$} & \multirow{2}{*}{$15 / 38$} \\
\hline & Day 2 & 90 & 61,013 & $0 / 4$ & 663 & 22,542 & $6 / 28$ & & & & \\
\hline \multirow[b]{2}{*}{ Dikwa Rd } & Day 1 & 26 & 17,455 & $9 / 0$ & 214 & 7276 & $14 / 5$ & \multirow[b]{2}{*}{25.5} & \multirow[b]{2}{*}{185} & \multirow[b]{2}{*}{$12 / 4$} & \multirow[b]{2}{*}{$24 / 11$} \\
\hline & Day 2 & 25 & 17,269 & $3 / 4$ & 156 & 5304 & $10 / 6$ & & & & \\
\hline \multirow{2}{*}{ Damasak Rd } & Day 1 & 96 & 65,584 & $27 / 0$ & 5 & 170 & $2 / 0$ & \multirow{2}{*}{78} & \multirow{2}{*}{4} & \multirow{2}{*}{$49 / 0$} & \multirow{2}{*}{$3 / 0$} \\
\hline & Day 2 & 60 & 40,981 & $22 / 0$ & 3 & 102 & $1 / 0$ & & & & \\
\hline \multirow{2}{*}{$\begin{array}{l}\text { Kashim } \\
\text { IbrahimRd }\end{array}$} & Day 1 & 178 & 121,112 & $16 / 23$ & 1488 & 50,592 & $18 / 33$ & \multirow{2}{*}{153.5} & \multirow{2}{*}{1283} & \multirow{2}{*}{$27 / 44$} & \multirow{2}{*}{$48 / 49$} \\
\hline & Day 2 & 129 & 88,215 & $11 / 21$ & 1078 & 36,652 & $30 / 16$ & & & & \\
\hline \multirow{2}{*}{ Gombe Rd } & Day 1 & 84 & 57,419 & $15 / 7$ & 385 & 13,090 & $13 / 15$ & \multirow{2}{*}{103.5} & 200 & $24 / 15$ & בר/20 \\
\hline & Day 2 & 123 & 84,023 & $19 / 8$ & 233 & 7922 & $16 / 7$ & & 30 & $34 / 10$ & 29122 \\
\hline & Total & & & & & & & 441 & 2283 & $128 / 86$ & $119 / 120$ \\
\hline & & & & A $(6$ & & & & 265 & & $60 / 40$ & $50 / 50$ \\
\hline $10 \mathrm{~W} 000$ & A lype oy & 11 & & N $(4$ & $\%)$ & & & 176 & & & \\
\hline & & & & A & & & & 143 & & & \\
\hline Detar Tue & 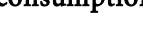 & Hit & Uay) & $\mathrm{N}$ & & & & 145 & 10 & & \\
\hline Total & solid biom & lass cons & amption ra & e (t/day) & & & & & 6 & & \\
\hline
\end{tabular}

Note: Average mass of charcoal (CHL) bag: $34 \mathrm{~kg}$; Wood type: Acacia/Neem (A/N). Average bulk density of acacia firewood (FWD): $540 \mathrm{~kg} / \mathrm{m}^{3}$ [21]; Average bulk density of neem firewood (FWD): $826 \mathrm{~kg} / \mathrm{m}^{3}$ [22].

actions towards a cleaner environment, the consumption of such solid biomass will continue to increase because of population and economic growth. High international energy prices may also affect a smooth shift to cleaner and more effi- 
cient use of energy sources. Use of biomass is not in itself a cause for concern but rather unsustainable use of the resource and inefficient energy conversion technologies will have serious adverse consequences for health (through exposure to indoor air pollution due to biomass combustion), the environment and economic development [3].

\subsection{Negative Effects of Biomass Fuel Consumption}

Reliance on biomass resources in Nigeria cannot be regarded as sustainable due to high rates of deforestation [26] [27] and negative environmental impacts. In most transition economies, the conversion technology of biomass to energy is efficient and the resources are generally managed in a sustainable way, whereas in Nigeria, the technologies and practices are much less efficient. Uses of three-stone fires, cook without ventilation or harvest at an unsustainable rate are common. Also, valuable time and effort are devoted to fuel collection instead of wealth creation. Environmental damage can also result, such as land degradation, deforestation and regional air pollution. Traditional stoves using biomass fuels emit large amounts of particulate matter, carbon monoxide (CO) and other noxious gases [28] and constant exposure to such indoor emissions whose concentrations are significantly higher than World Health Organization standards would have adverse effects on health, especially women and children. Table 2 below shows the total daily consumption of biomass fuels in mass (ton) and the resulting harmful air emissions due to their combustion.

\subsection{National Solid Biomass Consumption}

According to UN [34], the annual national consumption of solid biomass (fuelwood) for year 2014 was $19,753 \times 10^{3}$ cubic meters, which when projected to 2017 according to historical trends, will result to an increment of $10 \%$, i.e. 217,283 $\times 10^{3} \mathrm{~m}^{3}$. There is the need to determine the average national density of fuelwood in Nigeria to estimate the national solid biomass consumption rate in terms of mass.

\subsubsection{Average National Fuelwood Density}

Vegetation in Nigeria is characterised by various species of plants spread across the six different vegetation belts of the country. Each vegetation belt is characterised by certain tree species which are typical to it and are predominantly available. Such trees are usually used by the locals as firewood and charcoal to meet energy demands in households, markets and industries. These plant species have varying wood bulk densities [35] [36] [37] and therefore, the approximate average representative density of the country's fuelwood is necessary to convert the national fuelwood consumption given in volume [34] to mass for the purpose of this study. A study on the assessment of vegetation in Nigeria by Geomatics International [38] under the auspices of "Environmental Management Project" (funded by the World Bank) reveals the various dominant fuelwood plant species belonging to each of the six vegetation zones in the country. The average 
Table 2. Actual average rates of fuelwood consumption and air emissions in Maiduguri metropolis [29] [30] [31] [32] [33].

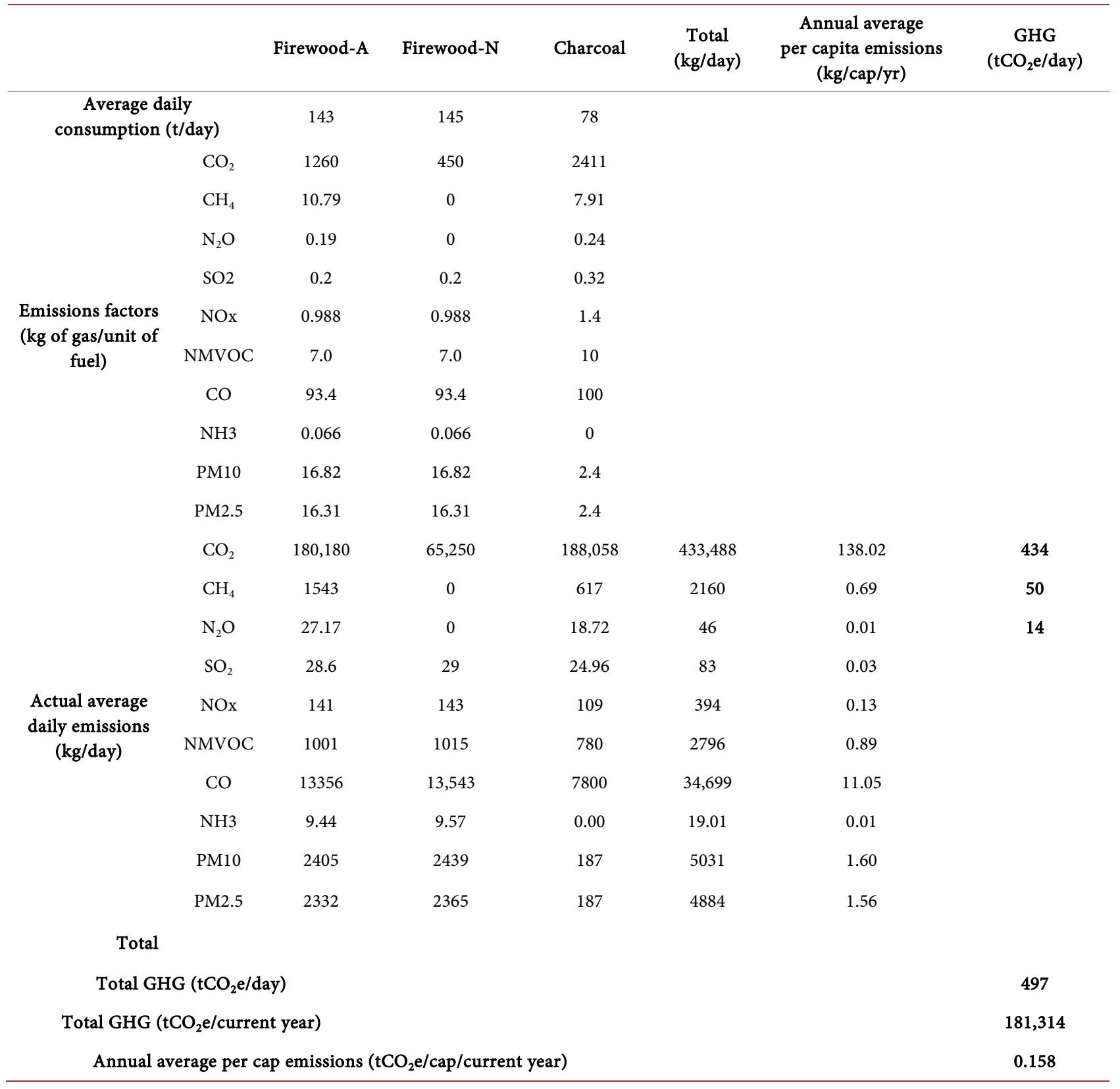

Note: 1) GWP for methane $\mathrm{CH}_{4}$ is 23 and for $\mathrm{N}_{2} \mathrm{O}$ is 296 [33]. 2) Population of Maiduguri is 1,146,397 [15]. 3) Annual $\mathrm{CO}_{2}$ emission is $433,488 \times 365 / 10^{6}=$ $158.23 \mathrm{kt} \mathrm{CO}_{2}$ or $433,488 \times 365 / 1,146,397=138.02 \mathrm{k} \mathrm{CO}_{2} / \mathrm{cap}$.

wood bulk densities of species belonging to a vegetation zone are then determined. The frequency of occurrence of these plant species will be directly related to the land area of their vegetation [39] [40]. The overall mean value of national (fresh green) wood density is therefore estimated from this information as presented in Table 3 below. The figure of $626 \mathrm{~kg} / \mathrm{m}^{3}$ is the national average fresh green wood density of fuelwood trees. For an air-dried seasoned firewood (usually $20 \%$ moisture content), density reduction is around $35 \%$ on average [41] [42]. This factor reduces the overall density from $626 \mathrm{~kg} / \mathrm{m}^{3}$ to $407 \mathrm{~kg} / \mathrm{m}^{3}$. 
Table 3. Average fuelwood density of Nigerian vegetation [34]-[39].

\begin{tabular}{|c|c|c|c|c|c|}
\hline S/no & Vegetation & $\begin{array}{l}\text { Land area } \\
\qquad\left(\mathrm{km}^{2}\right)\end{array}$ & $\begin{array}{l}\text { Land area ratio } \\
\text { (frequency of } \\
\text { occurrence, } f \text { ) }\end{array}$ & $\begin{array}{l}\text { Average wood bulk } \\
\text { density of } \\
\text { dominant plant } \\
\text { species, } \mathrm{D}\left(\mathrm{kg} / \mathrm{m}^{3}\right)\end{array}$ & $\begin{array}{l}\text { Density-frequency } \\
\text { Product (fxD) }\end{array}$ \\
\hline 1 & Sahel savanna & 71,150 & 8 & 703 & 5624 \\
\hline 2 & Sudan savanna & 321,550 & 36 & 694 & 24,984 \\
\hline 3 & Guinea savanna & 376,070 & 42 & 561 & 23,562 \\
\hline 4 & $\begin{array}{l}\text { Lowland } \\
\text { Rainforest }\end{array}$ & 89,630 & 10 & 550 & 5500 \\
\hline 5 & $\begin{array}{c}\text { Fresh water } \\
\text { swamp }\end{array}$ & 9000 & 1 & 553 & 553 \\
\hline \multirow[t]{2}{*}{6} & Mangrove & 15,000 & 2 & 896 & 1792 \\
\hline & & & 99 & & 62,015 \\
\hline \multicolumn{3}{|c|}{ Mean value of $D=\Sigma f D / \Sigma f\left(k g / \mathrm{m}^{3}\right)$} & & 626 & \\
\hline
\end{tabular}

\subsubsection{Fuelwood Consumption Rates}

The national fuelwood consumption rate in the country will then be $217,283 \times$ $10^{3} \mathrm{~m}^{3} \times 407 \mathrm{~kg} / \mathrm{m}^{3}=88.43 \mathrm{mt}$, as against the daily total of $366 \mathrm{t} /$ day or annual total of $133.6 \mathrm{kt} / \mathrm{yr}$ in Maiduguri. The current national share of biomass energy use in Maiduguri is therefore around $0.15 \%$. Using current population figures [15] [43], the per capita consumption stands at $0.465 \mathrm{t} /$ cap and $0.117 \mathrm{t} / \mathrm{cap}$ in Nigeria and Maiduguri respectively. The low percentage suggests that a major part of biomass fuel combustion in the country is occurring in other regions outside Maiduguri. This shows that utilization of biomass energy in other parts of the nation is higher than that in Maiduguri. Although according to [44], the percentage distribution of households by cooking fuel in Bornoas at 2010 was around $95.3 \%$ wood, making it the third highest state in the country after Yobe and Bauchi, this does not mean the state (represented by its capital) is the third highest consumer of biomass in terms of quantity (as support by the research results in terms of the national share in Maiduguri of $0.15 \%)$. This low consumption is further buttressed by Naibbi and Healey [45] and NBS [46] and could be a result of other controlling factors such as per capita consumption and population size in addition to poverty. Another factor is the reduced fuelwood business in the city due to the prevailing security situation in the state and the north-east in general. However, the overall perception is that there is a predominant culture of fuelwood use in the north-eastern part of Nigeria since dependence on biomassas energy source is strongly correlated with poverty levels [47], which is much common in the region [48]. The absence of this temporary restriction of biomass use will likely mean an increase in biomass consumption within Maiduguri metropolis and the entire north-east zone.

\subsection{A Possible Transition to Modern Fuels}

The combination of energy sources for cooking, baking and roasting can generally be categorised as: 1) Traditional such as dung, agricultural residues and 
fuelwood, 2) Intermediate such as charcoal and kerosene, 3) Modern such as LPG (liquefied petroleum gas), biogas, plant oils, DME (dimethyl ether) and electricity. According to IEA [49], about 1.3 billion people do not have electricity and 2.7 billion people still rely on traditional use of biomass as their primary fuel for cooking. Heavy dependence on biomass is concentrated in (but not confined to) rural areas. Almost half a billion people in urban areas also rely on these resources [3]. As incomes among poor families increase gradually, their preference may shift towards modern facilities for cleaner and better energy services. But a complete transition from traditional biomass to modern energy forms is not a linear process. The assertion that electricity substitutes for biomass might not be real because poor families tend to be selective in using energy services. Electricity is mainly dedicated to lighting, locomotive and communication devices in addition to occasional uses for cloth pressing and water boiling, while cooking which is a frequent and energy intensive area is mainly done with solid biomass and kerosene. In the absence of full access to electricity energy, which is recently about $58 \%$ in Nigeria [43] and about $28.5 \%$ in the North-east [46], electricity consumption is minimal and thus represents a small share of total household consumption in energy terms, especially in poor homes that do not have alternative electricity sources like off-grid generation system. Also, lack of electricity means absence of refrigeration and hence more cooking since food is spoilt and wasted.

The two common determinants in the transition from biomass to low emission energy use are fuel availability and affordability through free market forces and cultural preferences through government influence in a top-down manner. Alternative fuels and technologies may be available at reasonable cost but if a modern distribution infrastructure is not fully in place, households cannot obtain easy access to modern fuels, even if they are affordable. LPG penetration rates are low in Nigeria as in many developing countries, partly because distribution infrastructure is lacking [50]. Even when modern fuels are afford able, consumers may prefer using biomass if they remain relatively cheaper. The perception in poor societies that biomass is often free and readily available will seriously hamper a smooth transition to modern energy sources. Even when traditional biomass fuel is purchased, it is likely to be cheaper than the cheapest alternative clean fuel. The affordability of fuel combustion equipment is just as important as the affordability of fuels. The initial cost of acquiring low emission stove such as LPG stoves and LPG bottles may further discourage many users from switching away from biomass. In some cases, traditions determine the fuel choice regardless of fuel availability and income. For instance, even rich households keep a biomass stove for preparing special traditional food [3].

Therefore, the only feasible transition in heating technology in Maiduguri city (and in most developing societies) so far seems to be a transition to energy efficient biomass stoves. This makes technologies such as biolite camp stove very good options. The technology reduces energy consumption by about $50 \%$ in addition to emissions reductions of $90 \%$ [51] [52] [53]. The biolite stove is not yet 
available in developing countries (including Nigeria) due to its unfamiliarity and high cost. However, there are ongoing pilot programs in India, Ghana, Uganda and Kenya [54] for large-scale production of the technology through local entrepreneurship and it is expected that in the next few years, high availability will drive down costs, which in turn will stimulate the adoption of the technology and will become the dominant household equipment for heating in developing countries including Nigeria. An increased funding from both public and private sectors is likely to accelerate this transition.

\section{Conclusions}

The assessment of the consumption of solid biomass (fuelwood) in Maiduguri metropolis (the capital of Borno state in the north-eastern region of Nigeria) reveals consumption rates of firewood and charcoal of $288 \mathrm{~kg} / \mathrm{day}$ and $78 \mathrm{~kg} /$ day respectively. This is just about $0.15 \%$ of national biomass consumption rate. The per capita rate in Maiduguri stood at $0.117 \mathrm{t} / \mathrm{cap}$ as against the national figure of $0.465 \mathrm{t} / \mathrm{cap}$ in Nigeria. The low percentage in Maiduguri city is partly due to a reduced access to fuelwood trees in rural areas as result of the prevailing security situation in Borno state. The study also indicated the environmental consequence of biomass use in the city. The use of solid biomass for cooking, commercial business and industry is associated with indoor pollution and damage to health. Greenhouse gases emission rate is $497 \mathrm{t}$ COe/day or $181,314 \mathrm{t} \mathrm{CO}_{2} /$ year. The inefficient use of biomass energy in Maiduguri which is generally through the practice of open-fire three stone stoves has localized environmental effects and health implications, particularly, for regular users (women, children, bakers and roasters, etc.) who are often close by during the combustion process. Thus, respiratory related diseases due to indoor smoke are common. Deforestation with its attendant consequence is also prevalent. The absence of efficient and affordable energy services can severely damage public health and the environment in poor societies.

Two complementary approaches can improve the environmental issues associated with unsustainable consumption of biomass fuels. The first is promoting more efficient and sustainable use of traditional biomass and second is to encourage users to switch to modern cooking fuels and technologies. However, this is not a trivial societal change that can be caused by regular policy processes but will need a strategic, visionary, vigorous and concerted action by relevant actors (government, business, society and technology) to achieve such targets in the long term. Institutionalized government development strategies must be in place to promote sustainable, cleaner and more efficient use of fuels and technologies by addressing barriers to availability, accessibility, affordability and culture. A shift from (traditional) wood to (intermediate) charcoal, through the modern biolite stove to using low emission fuels such as LPG has a significant positive impact on the overall health risk factor. Moreover, the effects of deforestation are lessened and time is regained by women and children for more productive activities instead of gathering fuelwood for open fires. However, the appropriate 
energy mix within a society will depend on local circumstances such as per-capita incomes and the availability of alternative fuel and infrastructure system. Pioneers of low emission heating systems should focus on sustainable market development by using a market-based approach (free market forces) and top-down government regulation to penetrate the society. For cost to be low, manufacturing/transformation activities must be in large-scale and this would call for local entrepreneurship and skills development to stimulate local markets. Subsidies must be available to provide clean cook stoves to people in areas with high poverty rates. This will reduce damage to the environment and health and enhance standard of living amongst the citizenry.

\section{Acknowledgements}

This research was supported by the University of Maiduguri, Nigeria. We thank our colleagues who provided insight and expertise that greatly assisted the research. We also thank the Dean Faculty of Engineering, Prof. L.O. Onundi and the H.O.D. Civil \& Water Resources Engineering Department, Dr. Baba Shehu Waziri for their assistance and comments that greatly improved the quality of the manuscript.

\section{References}

[1] Food and Agriculture Organization of the United Nations (2007) Forests and Energy in Developing Countries. Forests and Energy Working Paper 2. http://www.fao.org/tempref/docrep/fao/010/k1140e/k1140e00.pdf

[2] Hall, D.O. and Moss, P.A. (1983) Biomass for Energy in Developing Countries. GeoJournal, 7, 5-14. https://link.springer.com/article/10.1007/BF00191854 https://doi.org/10.1007/BF00191854

[3] International Energy Agency (2006) World Energy Outlook 2006-Energy for Cooking in Developing Countries. OECD Publishing, Paris. http://dx.doi.org/10.1787/weo-2006-16-en

[4] Reddy, A.K.N. Smith, K.R. and Williams, R.H. (n.d.) World Energy Assessment: Energy and The Challenge of Sustainability-Rural Energy in Developing Countries. World Bank, Washington DC.

[5] Trossero, M.A. (n.d.) Wood Energy: The Way Ahead. FAO Corporate Document Repository. http://www.fao.org/docrep/005/y4450e/y4450e02.htm

[6] International Energy Agency (2002) World Energy Outlook, Chapter 13, Energy and Poverty ITDG (2002) Reducing Indoor Air Pollution in Rural Households in Kenya: Working with Communities to Find Solutions (ITDG Project 1998-2001).

[7] World Health Organization (2006) Fuel for Life: Household Energy and Health. WHO, Geneva.

[8] Karekezi, S., McDade, S., Boardman, B. and Kimani, J. (n.d.) Energy, Poverty, and Development.

http://www.iiasa.ac.at/web/home/research/Flagship-Projects/Global-Energy-Assess ment/GEA_Chapter2_development_hires.pdf

[9] International Energy Agency (2010) Energy Poverty-How to Make Modern Energy Access Universal? World Energy Outlook 2010. International Energy Agency (IEA), Paris. 
[10] National Population Commission (2004) Nigeria Demographic and Health Survey 2003-The DHS Program. https://www.dhsprogram.com/pubs/pdf/FR148/FR148.pdf

[11] International Agency for Research on Cancer (2017) Household Use of Solid Fuels. https://monographs.iarc.fr/ENG/Monographs/vol95/mono95-6.pdf

[12] Holland, E. (2017) Deforestation-Causes, Effects, and Solutions. https://futurism.media/deforestation-causes-effects-and-solutions

[13] Pachamama Alliance (2017) Effects of Deforestation. https://www.pachamama.org/effects-of-deforestation

[14] Google Earth (2017) Google Earth Pro. https://www.google.com/earth/download/gep/agree.html

[15] Population City (2017) Maiduguri Population. http://population.city/nigeria/maiduguri/

[16] National Oceanic and Atmospheric Administration (2016) Maiduguri Climate Normals 1961-1990.

[17] Climate Maiduguri (2016) Climate: Average Monthly Weather in Maiduguri, Nigeria. https://weather-and-climate.com/average-monthly-Rainfall-Temperature-Sunshine, Maiduguri,Nigeria

[18] Maiduguri, Nigeria Climate, Global Warming, and Daylight Charts and Data (n.d.) Climate Charts.

[19] Climate-Data.Org (2017) Climate: Maiduguri. https://en.climate-data.org/location/545/

[20] Google Earth (2017) Maiduguri City. https://www.google.com/earth/download/gep/agree.html

[21] Fantastic Floor (2015) Density Ratings for Various Species of Wood (KG per Cubic Meter). https://www.fantastic-floor.com/wooddensity.aspx

[22] Orwa, C., Mutua, A., Kindt, R., Jamnadass, R. and Anthony, S. (2009) Agroforestree Database: A Tree Reference and Selection guide Version 4.0. World Agroforestry Centre, Kenya.

[23] Ewah, J.O. (2014) Exploitation of Carbon Energy and the Integrity of Protected Rainforest Areas in Nigeria. International Journal of Humanities and Social Science, 4, 206-215. http://www.ijhssnet.com/journals/Vol_4_No_6_1_April_2014/21.pdf

[24] Grmek, M., Vertin, K. (2009) Socio-Economic Analysis of the Firewood Market. Quality Wood Project Report 2.2./2009, Project EIE/06/178/SI2.444403, Slovenia, 52 p. https://ec.europa.eu/energy/intelligent/projects/sites/iee-projects/files/projects/docu ments/quality_wood_socio_economic_analysis_of_the_firewood_markets.pdf

[25] Onoja, A.O. and Emodi, A.I. (2012) Economic Analysis of Fuelwood Production and Consumption: Evidence from a Nigerian State. British Journal of Management \& Economics, 2, 13-23.

http://www.journalrepository.org/media/journals/BJME_15/2011/Dec/1324989481OnojaandEmodi_2011BJME622.pdf

[26] Dickson, A. and Chris, I. (2005) An Analysis of Nigeria's Environmental Vision 2010. Journal of Environmental Policy \& Planning, 7, 341-365.

[27] Ibrahim, K.M. and Muhammad, S.I. (2015) A Review of Afforestation Efforts in Nigeria. International Journal of Advanced Research in Engineering and Applied Sciences, 4, 24-37. http://www.garph.co.uk/IJAREAS/Dec2015/3.pdf

[28] Smith, K.R., Rogers, J. and Cowlin, S.C. (2005) Household Fuels and Ill Health in Developing Countries: What Improvements Can Be Brought by LP Gas (LPG)? 
Paris, France, World LP Gas Association and Intermediate Technology Development Group.

[29] Emission Factors (2017) Emission Factors Used in the Estimations of Emissions from Combustion.

https://www.ssb.no/_attachment/291696/binary/95503?_version=547186

[30] Lokesh, A.C., Mahesh, N.S., Gowda, B., Kumar, R.K. and White, P. (2015) Neem Biodiesel-A Sustainability Study. Journal of Biomass to Biofuel, 1, 1-10. https://www.researchgate.net/profile/Adhappa_Lokesh/publication/273124762_Nee m_Biodiesel_-A_Sustainability_Study/links/54f7deb30cf210398e935e55/Neem-Biod iesel-A-Sustainability-Study.pdf

[31] Ministry of Environment (2016) Best Practices Methodology for Quantifying Greenhouse Gas Emissions: Including Guidance for Public Sector Organizations, Local Governments and Community Emissions. Victoria.

https://www2.gov.bc.ca/assets/gov/environment/climate-change/cng/methodology/ 2016-17-pso-methodology.pdf

[32] Staffell, I. (2011) The Energy and Fuel Data Sheet. University of Birmingham, Birmingham.

http://www.claverton-energy.com/wordpress/wp-content/uploads/2012/08/the_ene rgy_and_fuel_data_sheet1.pdf

[33] United States Environmental Protection Agency (2000) Research and Development; Greenhouse Gases from Small-Scale Combustion Devices in Developing Countries: Phase IIA. http://www.stoves.bioenergylists.org/en/emissions

[34] United Nation (2017) Nigeria: Fuelwood, Consumption. http://www.factfish.com/

[35] Adedeji, G.A., Ogunsanwo, O.Y. and John, J. (2004) Density Variations in Red Mangrove (Rhizophora racemosa GFW Meyer) in Onne, River State, Nigeria. International Journal of Science and Nature, 4, 165-168.

http://www.scienceandnature.org/IJSN_Vol4(1)M2013/IJSN-VOL4(1)13-29.pdf

[36] Food and Agriculture Organization of the United Nations (1997) Estimating Biomass and Biomass Change of Tropical Forests: A Primer. FAO Forestry Paper 134. http://www.nzdl.org/

[37] Food and Agriculture Organization of the United Nations (1997) Estimating Biomass and Biomass Change of Tropical Forests: A Primer. Corporate Document Repository. http://www.fao.org/docrep/w4095e/w4095e0c.htm

[38] Geomatics International (1998) The Assessment of Vegetation and Land Use Changes in Nigeria between 1976/78 and 1993/95. Environmental Management Project (World Bank Funded).

http://documents.worldbank.org/curated/en/611631468291342228/pdf/779940WP0 P0021210Box377320B00PUBLIC0.pdf

[39] Akeredolu, F. and Isichei, A.O. (1991) Emissions of Carbon, Nitrogen and Sulfur from Biomass Burning in Nigeria. In: Levine, J.S., Ed., Global Biomass Burning: Atmospheric, Climatic, and Biospheric Implications, MIT Press, Cambridge, 47-52. https://books.google.com.ng/

[40] Aregheore, E.M., Suttie, J.M., Reynolds, S.G. and Reynolds, S.G. (2009) Country Pasture/Forage Resource Profiles: Nigeria.

http://www.fao.org/ag/agp/agpc/doc/counprof/nigeria/nigeria.htm

[41] Kofman, P.D. (2010) Units, Conversion Factors and Formulae for Wood for Energy.

http://woodenergy.ie/media/coford/content/publications/projectreports/cofordcon nects/ht21.pdf 
[42] The Engineering ToolBox (n.d.) Wood Species-Moisture Content and Weight. https://www.engineeringtoolbox.com/weigt-wood-d_821.html

[43] World Bank (2017) Data Catalogue. https://data.worldbank.org/country/Nigeria

[44] National Bureau of Statistics (2011) Annual Abstract of Statistics. http://istmat.info/files/uploads/53129/annual_abstract_of_statistics_2011.pdf

[45] Naibbi, A.I. and Healey, R.G. (2013) Northern Nigeria's Dependence on Fuelwood: Insights from Nationwide Cooking Fuel Distribution Data. International Journal of Humanities and Social Science, 3, 160-173.

http://www.ijhssnet.com/journals/Vol_3_No_17_September_2013/17.pdf

[46] National Bureau of Statistics (2017) Annual Abstract of Statistics. Vol. 1. https://www.proshareng.com/admin/upload/reports/ANNUALABSTRACTSTATIS TICSVOLUME1.pdf

[47] Sa'ad, S. and Bugaje, I.M. (2016) Biomass Consumption in Nigeria: Trends and Policy Issues. Journal of Agriculture and Sustainability, 9, 127-157. http://infinitypress.info/index.php/jas/article/viewFile/1316/593

[48] National Bureau of Statistics (2012) Nigeria Poverty Profile 2010. http://www.nigerianstat.gov.ng/pdfuploads/Nigeria\%20Poverty\%20Profile\%202010. pdf

[49] International Energy Agency (2011) World Energy Outlook: Executive Summary. https://www.iea.org/Textbase/npsum/weo2011sum.pdf

[50] Ahmed, A.K. (n.d.) Domestic LPG Market Growth-Infrastructural Challenges \& Opportunities.

http://nigerialpgas.com/downloads/Domestic_LPG_Market_Growth_Infrastructura 1_Challenges_and_Opportunities.pdf

[51] Africa Clean Cooking Energy Solutions Initiative (2014) Clean and Improved Cooking in Sub-Saharan Africa. A Landscape Report. http://documents.worldbank.org/curated/en/164241468178757464/pdf/98664-REVI SED-WP-P146621-PUBLIC-Box393185B.pdf

[52] Energypedia (2017) Improved Cookstove: Biolite Home Stove. https://energypedia.info/wiki/Improved_Cookstove:_BioLite_Home_Stove

[53] Levine, E. (2015) Global Alliance for Clean Cookstoves-Clean Cooking Forum 2015.

http://www.cleancooking2015.org/wp-content/uploads/2015/05/Elliott-Levine-USDept-of-Energy.pdf

[54] Changemakers (2017) BioLite-A Cookstove That Reduces Air Pollution 95\%, while Generating Off-Grid Electricity.

https://www.changemakers.com/morehealth/entries/biolite-reducing-indoor-air-po llution-95 